\title{
PEG Recombinant Human Megakaryocyte Growth and Development Factor
}

National Cancer Institute

\section{Source}

National Cancer Institute. PEG Recombinant Human Megakaryocyte Growth and

Development Factor. NCI Thesaurus. Code C1719.

A pegylated formulation containing a recombinant growth factor with thrombopoietic activity. The recombinant human megakaryocyte growth and development factor (rHuMGDF) component of this formulation is a nonglycosylated, truncated form of the Mpl ligand. Mpl ligand, also known as thrombopoietin, stimulates the production of megakaryocyte precursor cells, megakaryocytes, and mature platelets. rHuMGDF is complexed with polyethylene glycol to prolong its half life in vivo and is used for the treatment and prevention of thrombocytopenia. 